\title{
PENGUIN, A MACINTOSH APPLICATION FOR ENTRY AND PRESENTATION OF RADIOCARBON-DATED SAMPLES
}

\author{
ANTONIO PETRI ${ }^{1}$ and CARLO BARONI \\ Dipartimento di Scienze della Terra, Università di Pisa and C.N.R. - Centro di Studio per la Geologia \\ Strutturale e Dinamica dell’Appennino, Via S. Maria 53, I-56126 Pisa, Italy
}

\begin{abstract}
Penguin is a Macintosh computer application that facilitates the use of CALIB 3.03, the ${ }^{14} \mathrm{C}$ age calibration program by Stuiver and Reimer (1993). Penguin offers an easy user interface based on the well-known Macintosh standard multiwindow environment to create and edit the CALIB 3.03 calibration files and to export data in text format. Penguin and CALIB interact at the file level, i.e., Penguin is capable of reading and writing files in CALIB formats. Files containing the data are created in the Penguin environment and then saved on disk in the Penguin format. Penguin allows multiple editing of the calibration parameters and recalibration of the list of samples without the need to insert any modifications manually throughout the list. Penguin can also be used to read already calibrated files in order to extract the "cal" ages and display them in a spreadsheet-like window.
\end{abstract}

\section{INTRODUCTION}

Penguin is a Macintosh computer application that facilitates the use of CALIB 3.03, the well-known ${ }^{14} \mathrm{C}$ age calibration program by Stuiver and Reimer (1993). ${ }^{2}$ The "Penguin project" emerged from our need for flexibility in managing data sets of ${ }^{14} \mathrm{C}$-dated samples (The name was suggested by the prettiest subject we were dealing with). In particular, we frequently need to update and calibrate sets of ${ }^{14} \mathrm{C}$ dates from marine organisms (Baroni and Orombelli 1991) or from organisms that lived or fed in the sea, such as penguins and seals (Baroni et al. 1991; Baroni 1994; Baroni and Orombelli 1994). Nevertheless, the program is also useful for managing and editing sets of calibrated dates of other origin.

Penguin is at an early stage of development and is currently used at the Earth Science Department of the University of Pisa (Italy). Its currently implemented capabilities reflect the needs of the researchers who deal with ${ }^{14} \mathrm{C}$ dates. Features are added or modified each time a new need arises from our work. This means that the look and the functionality of Penguin may change in future releases, particularly if users assist us by supplying observations and suggestions for adding capabilities and/or modifying existing ones. Furthermore, some tools for graphical processing are currently being studied and could be added shortly.

Penguin is free software and is available from glsun2.gl.rhbnc.ac.uk via anonymous FTP, in the directory /pub/mac/apps.

\section{PENGUIN CALIBRATION UTILITIES}

As is well known, the ${ }^{14} \mathrm{C}$ dates from remains of organisms that lived or fed in the sea are affected by an offset known as the "reservoir effect", induced by the depletion of ${ }^{14} \mathrm{C}$ in the ocean. This depletion is related to regional variations in oceanic and atmospheric circulation and its magnitude has also varied through time (Broecker and Olson 1961; Broecker, Peng and Engh 1980; Östlund and Stuiver 1980; Stuiver and Östlund 1980; Gordon and Harkness 1992). In the Antarctic Ocean, the reservoir effect is particularly elevated, owing to the dilution of circumantarctic water with glacial meltwater and by the upwelling of deep and old oceanic water (Harkness 1979; Omoto 1983;

\footnotetext{
${ }^{1}$ Present address: Department of Geology, Royal Holloway University of London, Egham, Surrey TW20 0EX, United Kingdom ${ }^{2}$ The current version of CALIB is available at http://weber.u.washington.edu/ qil/calib.html.
} 
Stuiver, Pearson and Braziunas 1986). Thus, the apparent ages yielded by Antarctic samples are anomalously old as a consequence of the very low level of ${ }^{14} \mathrm{C}$ concentration in Antarctic water; the error is estimated to be $>1000 \mathrm{yr}$ and varies with different organisms and materials (Harkness 1979; Omoto 1983; Stuiver et al. 1981; Stuiver, Pearson and Braziunas 1986; Whitehouse, Chinn and Höfle 1988, 1989; Björck et al. 1991; Gordon and Harkness 1992; Berkman and Forman 1996). In order to compare the ${ }^{14} \mathrm{C}$ dates obtained from Antarctic samples with ${ }^{14} \mathrm{C}$ ages derived elsewhere, the ${ }^{14} \mathrm{C}$ ages need to be corrected for the reservoir effect and calibrated as accurately as possible.

According to Stuiver, Pearson and Braziunas (1986) and Stuiver and Reimer (1993), the calibration procedure for marine-derived organisms requires the computation of a parameter, $\Delta R$, that is the constant difference in reservoir age of a regional part of the ocean and the world ocean. $\Delta R$ values can be determined if samples of known historical age are available (actually, only samples from organisms that died before the era of nuclear tests are suitable for this purpose). Such samples mainly derive from penguins and seals killed at the beginning of the century during the historical Antarctic expeditions (Stuiver et al. 1981; Mabin 1985, 1986; Orombelli 1988; Whitehouse, Chinn and Höfle 1988, 1989; Björk et al. 1991). Recently, dates from shells of known age have been supplied as well (Berkman and Forman 1996).

Table 1 lists ${ }^{14} \mathrm{C}$ dates of known-age samples; it can be observed that the conventional ages span a wide time interval. Therefore, in order to perform the best possible calibration, different $\Delta \mathrm{R}$ values should be applied to different sets of ${ }^{14} \mathrm{C}$ dates obtained from different organisms. Namely, ${ }^{14} \mathrm{C}$ dates from penguin remains should be calibrated using a $\Delta R$ value derived only from penguin samples of known age ( $\Delta R=688 \pm 55$ is the weighted mean of seven values from penguin remains; $\Delta R=656$ \pm 55 is the weighted mean of three values from Adélie penguin remains only).

TABLE 1. Radiocarbon Dates from Samples of Known Age from Antarctica

\begin{tabular}{|c|c|c|c|c|c|c|}
\hline Sample no. & Location & Material & $\begin{array}{l}\text { Historical } \\
\text { age }(\mathrm{AD})\end{array}$ & $\begin{array}{l}\text { Conv. age } \\
\left({ }^{14} \mathrm{C} \text { yr BP }\right)\end{array}$ & $\begin{array}{c}\Delta R \\
\left({ }^{14} \mathrm{C} \text { yr BP }\right)\end{array}$ & Reference \\
\hline Lu31101 & Hope Bay & Penguin bones & 1903 & $1280 \pm 50$ & $816 \pm 50$ & Bjork et al. 1991 \\
\hline 4432 & Cape Royds & Adélie penguin flesh & 1904 & $925 \pm 75$ & $462 \pm 75$ & $\begin{array}{l}\text { Geyh and Wirth in White- } \\
\text { house, Chinn and Hofle } 1988\end{array}$ \\
\hline 4433 & Cape Adare & Flesh mew of prey & 1902 & $1125 \pm 90$ & $660 \pm 90$ & $\begin{array}{l}\text { Geyh and Wirth in White- } \\
\text { house et al. } 1988\end{array}$ \\
\hline QL173 & Inexpressible Is. & Emperor penguin & 1912 & $1300 \pm 50$ & $838 \pm 50$ & Stuiver et al. 1981 \\
\hline QL171 & Inexpressible Is. & Weddell seal & 1912 & $1390 \pm 40$ & $928 \pm 40$ & Stuiver et al. 1981 \\
\hline NZ6339A & Inexpressible Is. & Emperor penguin bones & 1912 & $1065 \pm 50$ & $603 \pm 50$ & Mabin 1985 \\
\hline NZ6327A & Inexpressible Is. & Weddell seal bones & 1912 & $1760 \pm 55$ & $1298 \pm 55$ & Mabin 1985 \\
\hline NZ6842A & Inexpressible Is. & $\begin{array}{l}\text { Adélie penguin bones } \\
\text { and flesh }\end{array}$ & 1912 & $1060 \pm 45$ & $598 \pm 45$ & Whitehouse et al. 1988 \\
\hline NZ6872 & Inexpressible Is. & $\begin{array}{l}\text { Charcoal from seal } \\
\text { blubber stove }\end{array}$ & 1912 & $1240 \pm 45$ & $778 \pm 45$ & $\begin{array}{l}\text { Greenfield in Whitehouse et } \\
\text { al. } 1988\end{array}$ \\
\hline GX-12759 & Inexpressible Is. & Seal bones & 1912 & $1175 \pm 75$ & $713 \pm 75$ & Orombelli 1988 \\
\hline NZ7079A & Cape Evans & $\begin{array}{l}\text { Emperor penguin bone } \\
\text { collagen }\end{array}$ & 1916 & $1105 \pm 55$ & $642 \pm 55$ & Mabin 1986 \\
\hline NZ7076A & Cape Evans & $\begin{array}{l}\text { Emperor penguin flesh } \\
\text { and feathers }\end{array}$ & 1916 & $1220 \pm 55$ & $757 \pm 55$ & Mabin 1986 \\
\hline NZ6851A & Cape Evans & $\begin{array}{l}\text { Weddell seal bone col- } \\
\text { lagen }\end{array}$ & 1916 & $1610 \pm 80$ & $1147 \pm 80$ & Mabin 1986 \\
\hline GX-18581 & $68^{\circ} 30^{\prime} \mathrm{S}-67^{\circ} 00^{\prime} \mathrm{W}$ & Adamussium colbecki & 1940 & $1476 \pm 39$ & $1001 \pm 39$ & Berkman and Forman 1996 \\
\hline GX-18582 & $67^{\circ} 52^{\prime} \mathrm{S}-67^{\circ} 17^{\prime} \mathrm{W}$ & Adamussium colbecki & 1940 & $1416 \pm 40$ & $941 \pm 40$ & Berkman and Forman 1996 \\
\hline AA 14785 & $68^{\circ} 47^{\prime} \mathrm{S}-90^{\circ} 35^{\prime} \mathrm{W}$ & Neobuccinum eotoni & 1917 & $1215 \pm 57$ & $750 \pm 57$ & Berkman and Forman 1996 \\
\hline GX-19205 & $78^{\circ} 30^{\prime} \mathrm{S}-164^{\circ} 20^{\prime} \mathrm{W}$ & Thracia meridionalis & 1935 & $1278 \pm 62$ & $798 \pm 62$ & Berkman and Forman 1996 \\
\hline
\end{tabular}


With our Penguin program it is easy to recalibrate the set of data using both the mean value calculated from all the available samples or different $\Delta$ Rs obtained from penguin remains only. Furthermore, regional values can be calculated and compared for different sets of data.

Calibration is performed by the computer program CALIB (Stuiver and Reimer 1993); it allows the manual insertion of the data or can take as input a text file that can be created with a word processor. Normally, sample data (code, locality, description) are maintained using common commercial database programs, although the latter are not able either to export data directly in CALIB file format or to import data results (mainly calibrated age ranges) from CALIB output text files; in both cases data must be transferred one at time by retyping or through a tedious copy-and-paste process. Alternatively, sample data can be kept in CALIB input text files and handled with a word processor. However, because such programs are not aware of the format of those files, it is very easy to accidentally modify their structure, making them unreadable by CALIB.

Penguin's main goal is data management, focusing on data exchange with CALIB files in order to speed up the recalibration procedure. Penguin allows easy maintenance of sample data files, much like a database application. In our view, the program is particularly suited for the calibration procedure when one of the following conditions applies: 1 ) new ${ }^{14} \mathrm{C}$ dates are to be added to the set of data; 2) new samples of known age are supplied. In the first case, only the new conventional ages are to be calibrated, using one or more $\Delta R$ values. In the latter case, the $\Delta R$ values must be recalculated and the existing sets of ${ }^{14} \mathrm{C}$ dates must be recalibrated.

The usefulness of Penguin can be explained via an example (see the flow chart in Fig. 1). If we assume that new penguin remains (either bone or flesh) of historical known age have been discovered and dated, the existing $\Delta R$ value based on penguin remains must be updated in order to take into account the new datum (actually a weighted mean is computed of all the $\Delta R$ values derived from each dated sample). Then, this new $\Delta R$ value is used to recalibrate all the penguin ${ }^{14} \mathrm{C}$ dates.

If we have our sample data in a Penguin file called "MySamples" (Fig. 2), all we have to do is to open this file, assign the new $\Delta R$ value to all samples contained in the file and save a copy of the file in CALIB format. At this point we can use CALIB to calibrate all the dates. Calibration results are collected by CALIB in one

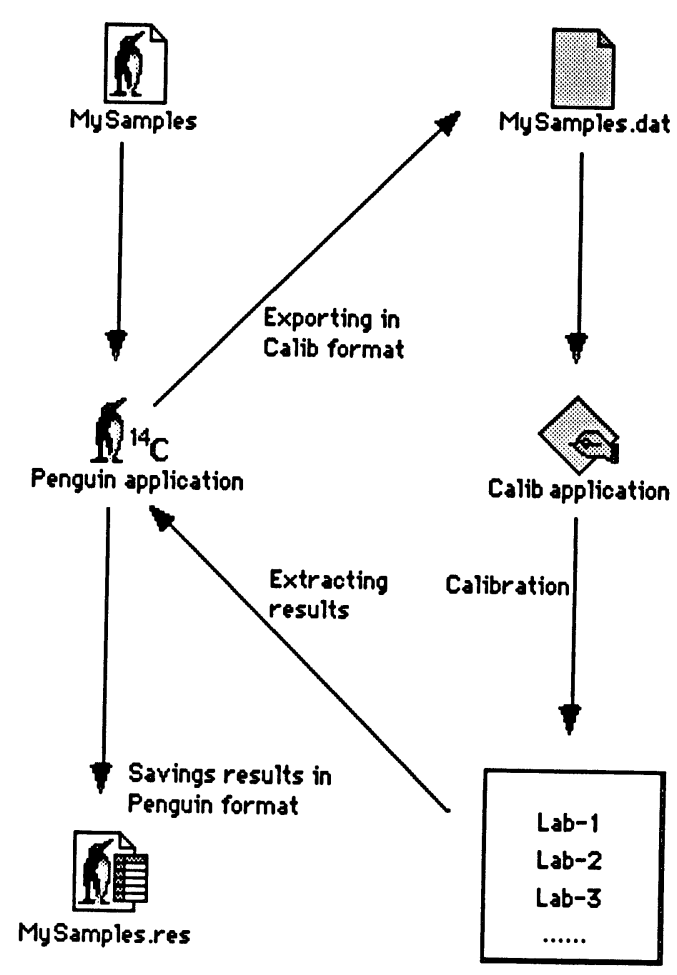

Fig. 1. Flowchart showing the role of Penguin in the calibration process. Data are kept in Penguin data files and CALIB input files are generated only when ${ }^{14} \mathrm{C}$ dates need to be calibrated. Penguin then puts into a unique file the calibration results extracted from each output file created by CALIB. 


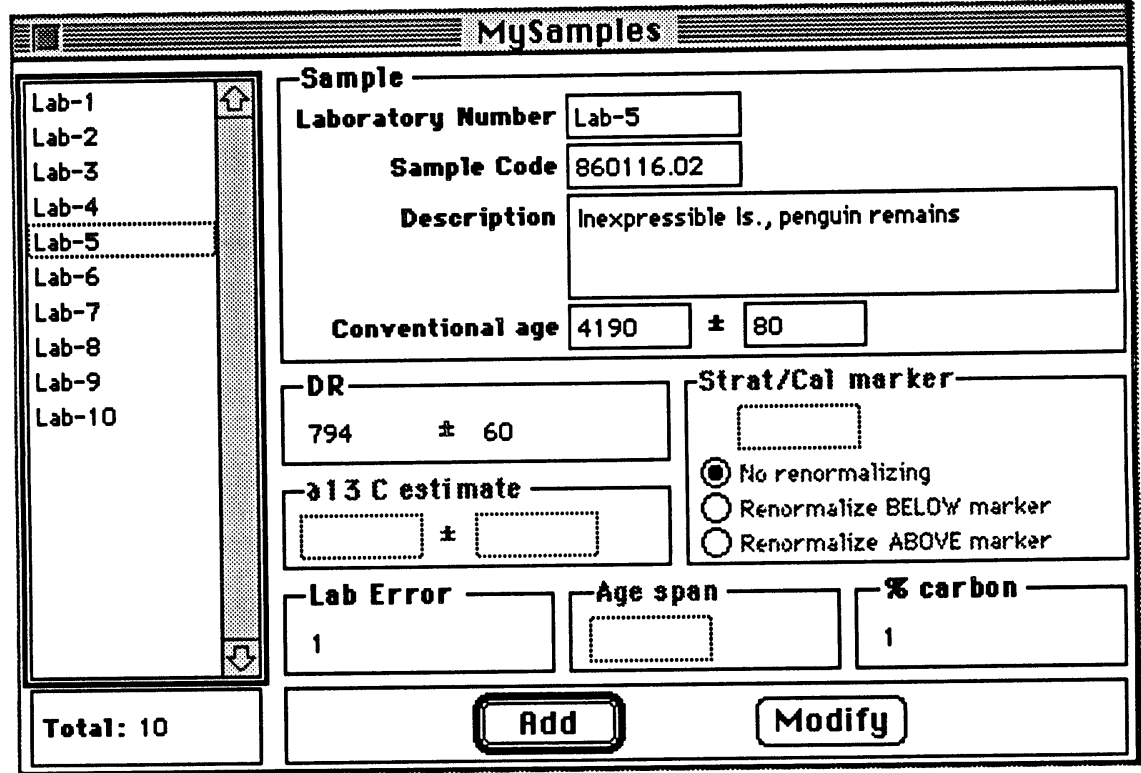

Fig. 2. Penguin allows easy editing of sample data files. Sample records are selected through the list on the left side of the window. Text boxes and radio buttons are provided for editing the content of the fields.

file for each sample, so after a calibration session there are as many files as the number of samples contained in the original input file. With Penguin, all these files can be parsed in order to extract the calibration results, which can be saved in unique file (Fig. 3). The current release of Penguin accepts only the calibrated age ranges from CALIB output files; future releases will allow extraction of all the other information. Furthermore, Penguin allows calibration results to be exported in standard text format files (variable-sized records with variable-sized fields separated by a tab character or comma) that can be directly read by database or spreadsheet programs.

Following a basic rule, common sample data should be kept in a Penguin file, which can be edited by either adding, deleting or modifying sample records; CALIB input files should be created only

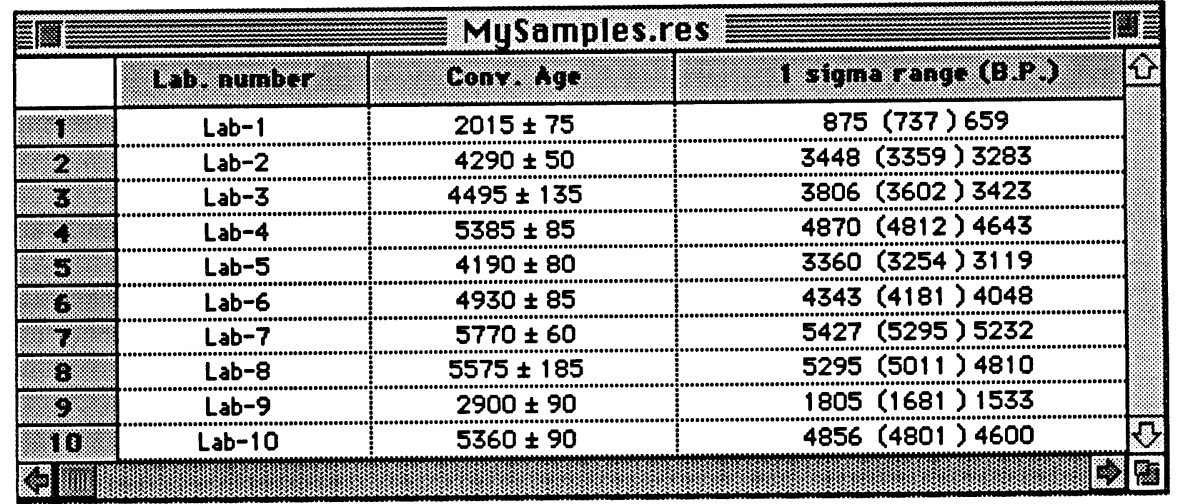

Fig. 3. Calibration results are displayed in a spreadsheet-like window 
for calibration purposes and then deleted when they are no longer needed. Of course, for each set of ${ }^{14} \mathrm{C}$ dates there will be as many Penguin calibration result files as the number of times the same set of dates has been calibrated.

\section{ACKNOWLEDGMENTS}

This work has been carried out within the framework of the Italian Antarctic Research Programme and was financially supported by ENEA through a joint research program on Antarctic Earth Sciences with the University of Siena.

\section{REFERENCES}

Baroni, C. 1994 Notes on Late-Glacial retreat of the Antarctic ice sheet and Holocene environmental changes along the Victoria Land coast. Memoirs of the $\mathrm{Na}$ tional Institute of Polar Research (Tokyo), Special Issue, 50: 85-87.

Baroni, C., Belluomini, G., Branca, M. E., Improta, S. and Orombelli, G. 1991 Radiocarbon dates from Terra Nova Bay (Northern Victoria Land, Antarctica): Conventional and calibrated ages. Memorie della Societd Geologica Italiana 46: 81-92.

Baroni, C. and Orombelli, G. 1991 Holocene raised beaches at Terra Nova Bay, Victoria Land, Antarctica. Quaternary Research 36: 157-177.

1994 Abandoned penguin rookeries as Holocene palaeoclimatic indicators in Antarctica. Geology 22: 23-26.

Berkman, P. A. and Forman, S. L. 1996 Pre-bomb radiocarbon and the reservoir correction for calcareous marine species in the southern ocean. Geophysical Research Letters 23(4): 363-366.

Björk, S., Hjort, C., Ingólfsson, O. and Skog, G. 1991 Radiocarbon dates from the Antarctic peninsula Region. Problems and potential. Quaternary Proceedings 1: 55-65.

Broecker, W. S. and Olson, E. A. 1961 Lamont radiocarbon measurements VII. Radiocarbon 3: 176-204.

Broecker, W. S., Peng, T. H. and Engh, R. 1980 Modeling the radiocarbon system. In Stuiver, M. and Kra, R., eds., Proceedings of the 10 th International ${ }^{14} \mathrm{C}$ Conference. Radiocarbon 22(3): 565-598.

Gordon, J. E. and Harkness, D. D. 1992 Magnitude and geographic variation of the radiocarbon content in Antarctic marine life: Implications for reservoir corrections in radiocarbon dating. Quaternary Science Reviews 11: 697-708.

Harkness, D. D. 1979 Radiocarbon dates from Antarctica. British Antarctic Survey Bulletin 47: 43-59.

Mabin, M. C. G. $1985{ }^{14} \mathrm{C}$ ages for "Heroic Era" penguin and seal bones from Inexpressible Island, Terra Nova
Bay, North Victoria Land. New Zealand Antarctic Record 6(2): 24-25.

Mabin, M. C. G. $1986{ }^{14} \mathrm{C}$ ages for "Heroic Era" penguin and seal remains from Cape Evans, McMurdo Sound. New Zealand Antarctic Record 7(2): 19-20.

Omoto, K. 1983 The problem and significance of radiocarbon geochronology in Antarctica. In Oliver, R. L, James, P. R. and Jago, J. B., eds., Antarctic Earth Science. Cambridge, Cambridge University Press: 450452.

Orombelli, G. 1988 Le spiagge emerse oloceniche della Baia Terra Nova (Terra Vittoria, Antartide). Atti della Accademia Nazionale dei Lincei, VIII, 81 (1987): 403-416.

Östlund, H.G. and Stuiver, M. 1980 GEOSECS Pacific Radiocarbon. Radiocarbon 22(1): 25-53.

Stuiver, M., Denton, G. H., Hughes, T. and Fastook, J. L. 1981 History of the Marine Ice Sheet in West Antarctica during the last glaciation: A working hypothesis. In Denton, G. H. and Hughes, T., eds., The Last Great Ice Sheets. New York, John Wiley \& Sons: 319-369.

Stuiver, M. and Östlund, H. G. 1980 GEOSECS Atlantic Radiocarbon. Radiocarbon 22(1): 1-24.

Stuiver, M., Pearson, G. W. and Braziunas, T. 1986 Radiocarbon age calibration of marine samples back to $9000 \mathrm{cal}$ yr BP. In Stuiver, M. and Kra, R., eds., Calibration Issue. Radiocarbon 28(2B): 980-1021.

Stuiver, M. and Reimer, P. J. 1993 Extended ${ }^{14} \mathrm{C}$ data base and revised CALIB $3.0{ }^{14} \mathrm{C}$ age calibration program. In Stuiver, M., Long, A. and Kra, R. S., eds., Calibration 1993. Radiocarbon 35(1): 215-230.

Whitehouse, I. E., Chinn, T. J. and Höfle, H. C. 1988 Radiocarbon contaminated penguin bones from Terra Nova Bay, Antarctica. New Zealand Antarctic Record 8(3): 11-23.

1989 Radiocarbon dates from raised beaches, Terra Nova Bay, Antarctica. Geologisches Jahrbuch E38: 331-334. 